\title{
Crustal S-wave velocity structure across the northeastern South China Sea continental margin: implications for lithology and mantle exhumation
}

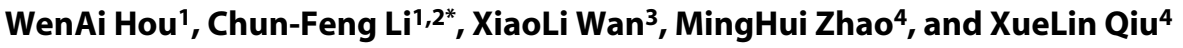 \\ ${ }^{1}$ Institute of Marine Geology and Resources, Zhejiang University, Zhoushan Zhejiang 316021, China; \\ 2Laboratory for Marine Mineral Resources, Qingdao National Laboratory for Marine Science and Technology, Qingdao 266237, China; \\ ${ }^{3}$ State Key Laboratory of Marine Geology, Tongji University, Shanghai 200092, China; \\ ${ }^{4}$ South China Sea Institute of Oceanology, Chinese Academy of Sciences, Guangzhou 510301, China
}

\begin{abstract}
The northeastern margin of the South China Sea (SCS), developed from continental rifting and breakup, is usually thought of as a non-volcanic margin. However, post-spreading volcanism is massive and lower crustal high-velocity anomalies are widespread, which complicate the nature of the margin here. To better understand crustal seismic velocities, lithology, and geophysical properties, we present an S-wave velocity $\left(V_{\mathrm{S}}\right)$ model and a $V_{\mathrm{P}} / V_{\mathrm{S}}$ model for the northeastern margin by using an existing $\mathrm{P}$-wave velocity $\left(V_{\mathrm{P}}\right)$ model as the starting model for 2-D kinematic $S$-wave forward ray tracing. The Mesozoic sedimentary sequence has lower $V_{\mathrm{P}} / V_{\mathrm{S}}$ ratios than the Cenozoic sequence; in between is a main interface of P-S conversion. Two isolated high-velocity zones (HVZ) are found in the lower crust of the continental slope, showing S-wave velocities of $4.0-4.2 \mathrm{~km} / \mathrm{s}$ and $V_{\mathrm{P}} / V_{\mathrm{S}}$ ratios of $1.73-1.78$. These values indicate a mafic composition, most likely of amphibolite facies. Also, a $V_{\mathrm{P}} / V_{\mathrm{S}}$ versus $V_{\mathrm{P}}$ plot indicates a magnesium-rich gabbro facies from post-spreading mantle melting at temperatures higher than normal. A third high-velocity zone ( $\left.V_{\mathrm{P}}: 7.0-7.8 \mathrm{~km} / \mathrm{s} ; V_{\mathrm{P}} / V_{\mathrm{s}}: 1.85-1.96\right)$, 70-km wide and 4-km thick in the continent-ocean transition zone, is most likely to be a consequence of serpentinization of upwelled upper mantle. Seismic velocity structures and also gravity anomalies indicate that mantle upwelling/ serpentinization could be the most severe in the northeasternmost continent-ocean boundary of the SCS. Empirical relationships between seismic velocity and degree of serpentinization suggest that serpentinite content decreases with depth, from $43 \%$ in the lower crust to $37 \%$ into the mantle.
\end{abstract}

Keywords: South China Sea; continental margin; crustal structure; converted S-wave; $V_{\mathrm{P}} / V_{\mathrm{S}}$ ratio; lithology; serpentinization

Citation: Hou, W. A., Li, C.-F., Wan, X. L., Zhao, M. H., and Qiu, X. L. (2019). Crustal S-wave velocity structure across the northeastern South China Sea continental margin: implications for lithology and mantle exhumation. Earth Planet. Phys., 3(4), 314-329.

http://doi.org/10.26464/epp2019033

\section{Introduction}

Passive continental margin provides critical constraints on the processes of rifting and eventual rupturing of the continental lithosphere. The northeastern continental margin of the South China Sea (SCS), which has been well-preserved, has experienced a transition from late Mesozoic subduction to Cenozoic continental rifting and subsequent seafloor spreading (Shi HS and Li CF, 2012; Taylor and Hayes, 1983) (Figure 1).

Multi-channel reflection and deep refraction seismic surveys (Gao JW et al., 2015; Savva et al., 2014; Yan P et al., 2006) show features akin to magma-poor margins in the northeastern SCS. These features include hyperextension of the continental crust, detachment faulting, and an absence of seaward dipping reflectors. Hence, it has been argued that the northeastern margin of the SCS is non-volcanic. However, massive post-spreading volcanism

Correspondence to: C-F Li, cfli@zju.edu.cn

Received 27 FEB 2019; Accepted 20 MAY 2019.

Accepted article online 06 JUN 2019.

C 2019 by Earth and Planetary Physics. and a lower crustal high-velocity layer (with P-wave velocity of $7.0-7.6 \mathrm{~km} / \mathrm{s}$, higher than the normal lower crustal velocity of 6.4-6.9 km/s but lower than the uppermost mantle velocity of 8 $\mathrm{km} / \mathrm{s}$; Christensen and Mooney, 1995) are also ubiquitous (Li YQ et al., 2017; Nissen et al., 1995; Wang TK et al., 2006; Wei XD et al., 2011; Zhao MH et al., 2010). The study of high-velocity anomalies is crucial to an understanding of the process of continental rifting and breakup.

The origin of lower crustal high-velocity anomalies in the SCS remains a subject of debate. Based on a two-ship expanding spread profiling, Nissen et al. (1995) suggested that they could be due to the underplating of magmatic material during rifting. Others have ascribed them to post-spreading magmatism (Yan P et al., 2001; Zhao MH et al., 2010). Based on numerical modeling, Song TR (2016) suggested that the high-velocity layer near the continentocean boundary (COB) could represent the exhumation of serpentinized upper mantle. Wan KY et al. (2017) suggested that the high-velocity layer underlying the transitional crust is related to Cenozoic decompression melting, whereas that beneath the Dongsha Rise further north is associated with the Mesozoic sub- 
duction of the Paleo-Pacific plate.

These controversies are partly due to lack of lithologic information, which cannot be easily derived. The $V_{\mathrm{P}} / V_{\mathrm{S}}$ ratio is particularly sensitive to the porosity (Castagna et al., 1985) and quartz content of rocks (Christensen, 1996), and can be used to predict the lithology (Neidell, 1985). $V_{\mathrm{P}} / V_{\mathrm{S}}$ ratios can help distinguish between felsic (quartz rich) and mafic (quartz poor) crystalline rocks (Mjelde et al., 2003). Hence, acquisition of additional shear (S-) wave velocities $\left(V_{S}\right)$ should be helpful in further constraining the elastic properties of the crust.

Based on both field seismic experiments and laboratory measurements, Holbrook et al. (1992) arrived at $V_{\mathrm{P}} / V_{\mathrm{S}}$ ratios for different crystalline basement compositions; they found that $V_{\mathrm{P}} / V_{\mathrm{S}}$ ratios vary from 1.71 in granite (felsic) and 1.78 in granodiorite, to 1.84 in gabbro (mafic). Using $V_{\mathrm{p}} / V_{\mathrm{S}}$ structures derived from Ocean Bottom Seismometer (OBS) data, Zhao MH et al. (2010) and Wei XD et al. (2011) reported a regional high-velocity layer of mafic composition in the northern continental margin of the SCS. However, no such study has been carried out near the COB, where the Moho depth is much shallower and exhumation of serpentinized mantle peridotite could exist.

In this study, we applied converted S-wave seismic phases to constrain the crustal lithology structure along a transect in the northeastern margin of the SCS, focusing on the composition of high velocity anomalies, possible serpentinization, and their geodynamic origins.

\section{Tectonic Setting}

The SCS has undergone a complete Wilson cycle in its evolutionary history. The SCS oceanic lithosphere is being subducted beneath the Luzon arc along the Manila Trench (Bautista et al., 2001). The western margin of the SCS is affected by the Ailao Shan-Red River strike-slip shear zone (Leloup et al., 1995). The southern margin of the SCS collided with Borneo (Ding WW et al., 2016; Sun Z et al., 2009; Zhao MH et al., 2010). The north margin has experienced multiple episodes of rifting (Taylor and Hayes, 1980). There are also well-preserved Mesozoic sequences that can provide rich information on the pre-rifting geological process of the SCS (Li C-F et al., 2008; Shi HS and Li C-F, 2012; Fan CY et al., 2017; Wan KY et al., 2017).

The complicated and fascinating features of the SCS have led to substantial discussions of its spreading time and rifting mechanism. Magnetic data show a general northeast-southeast opening of the SCS during the early Oligocene-Miocene (Taylor and Hayes, 1983; Li C-F et al., 2010). Based on newly acquired deep towed magnetic anomalies and International Ocean Discovery Program Expedition 349 cores, Li C-F et al. (2014) found that the initial seafloor spreading started around $34 \mathrm{Ma}$ in the northeastern SCS. At round $23.6 \mathrm{Ma}$, there was a southward ridge jump by $\sim 20 \mathrm{~km}$ in the East Subbasin; coevally, the Southwest Subbasin started to spread. The seafloor spreading terminated at $\sim 15 \mathrm{Ma}$ in the East Subbasin and at $\sim 16 \mathrm{Ma}$ in the Southwest Subbasin (Li C-F et al., 2014).

Tapponnier et al. (1982) and Briais et al. (1993) proposed that the collision between the Indian and the Eurasian plates resulted in a southward escape of the southeastern margin of the Tibetan Plateau, forming the large Ailaoshan-Red Sea strike-slip fault with a lateral movement of more than $500 \mathrm{~km}$, which resulted in extension of the SCS. Another leading hypothesis argued that the slabpull force from the subduction of the proto-SCS could be the main driver of the opening of the SCS (Hall and Spakman, 2002; Pubellier et al., 2004).

The northern continental margin of the SCS developed a wide (100-300 km), highly thinned, and magmatically modified continental crust (Yan P et al., 2001; Song TR, 2016). One of the most dominant features of the crustal structure in the northern margin of the SCS is the Dongsha Rise (Figure 1), which falls in a NE-trending high magnetic anomaly belt (Li C-F et al., 2008). Inversion results indicate that this high magnetic anomaly is produced by 2.5$6 \mathrm{~km}$ thick magnetic bodies in a $\sim 150 \mathrm{~km}$ wide zone (Hu DK et al., 2008), buried mostly in the upper crust at depths from $\sim 2$ to $\sim 20$ km (Li C-F et al., 2008). Extensive late Mesozoic magmatic rocks related to the subduction of the Paleo-Pacific plate are found in south China, including those responsible for the high magnetic anomaly of the Dongsha Rise (Li C-F et al., 2008; Zhou D et al., 2006).

\section{Seismic Data Acquisition and Preprocessing}

A marine coincidental reflection and refraction seismic survey was conducted in 2016 by the R/V shiyan-2 of the South China Sea Institute of Oceanology (SCSIO), Chinese Academy of Sciences. The seismic source consisted of four large-volume Bolt air guns with a total volume of $6000 \mathrm{in}^{3}(98.3225 \mathrm{~L})$, fired every $90 \mathrm{~s}$. A total number of 15 OBSs (each with three components and one hydrophone) were deployed in $\sim 18 \mathrm{~km}$ intervals from the Chaoshan Depression to the East Subbasin of the SCS (Figure 1); 14 of them returned good data (OBS06 was lost). The OBS data were sampled in $4 \mathrm{~ms}$ intervals. Coincidental four-channel reflection seismic data were also collected to define shallow structures (Figure 2a).

Data preprocessing consists of data format conversion, correction of shooting time and shot/OBS positions, and deconvolution (Wan XL, 2018). A band-pass filtering of corner frequencies of 3,4 , 8 and $10 \mathrm{~Hz}$ was applied. The converted S-wave data were extracted from the horizontal components of OBS recordings. Because the OBSs were gimballed on the seafloor, the orientation of the horizontal components is arbitrary. Therefore, an energy scanning method (Zhang L et al., 2016) was applied to find the polarization angle, and the horizontal components were then rotated into radial and transverse directions with respect to the shot line. The S-wave energy will be primarily in the radial component.

\section{Seismic Velocity Modeling}

\subsection{Initial P-Wave Velocity Model}

Wide-angle compressional ( $\mathrm{P}$-) wave refraction and reflection travel time tomography has recently been completed by Wan XL (2018), based on 2-D forward ray tracing (Zelt and Smith, 1992). The final $V_{\mathrm{P}}$ model (Figure $2 \mathrm{~b}$ ) reveals a $3-6 \mathrm{~km}$ thick Mesozoic sedimentary layer with velocities of $4.3-5.3 \mathrm{~km} / \mathrm{s}$ in the Chaoshan Depression; this unit pinches out in the COB below OBS11 and 


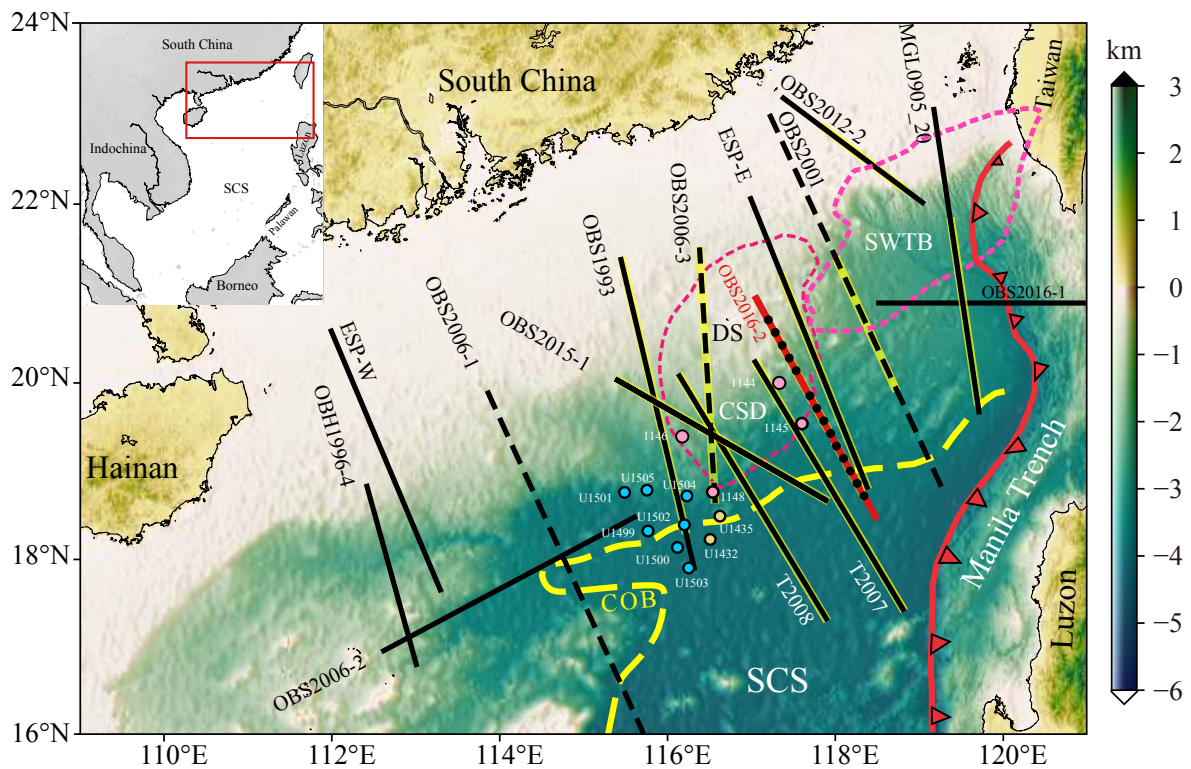

Figure 1. Locations of deep refraction seismic profiles across the Northern South China Sea continental margin. The red line represents data acquired in 2016 (this study) with black dots marking OBS positions; black lines show the positions of existing OBS profiles; black dashed lines indicate profiles where S-wave velocity structures have been studied. The yellow dashed curve refers to the continent-ocean boundary (COB) (Li C-F and Song TR, 2012; Song TR, 2016). Yellow hatched lines show where lower crustal high-velocity layers were revealed. Pink circles mark the drill sites of Ocean Drilling Program Leg 184; orange and blue circles mark the International Ocean Discovery Program (IODP) Expedition 349 and IODP Expeditions 367, 368, 368X, respectively. CSD: Chaoshan Depression, SWTB: Southwest Taiwan Basin, DS: Dongsha Rise.
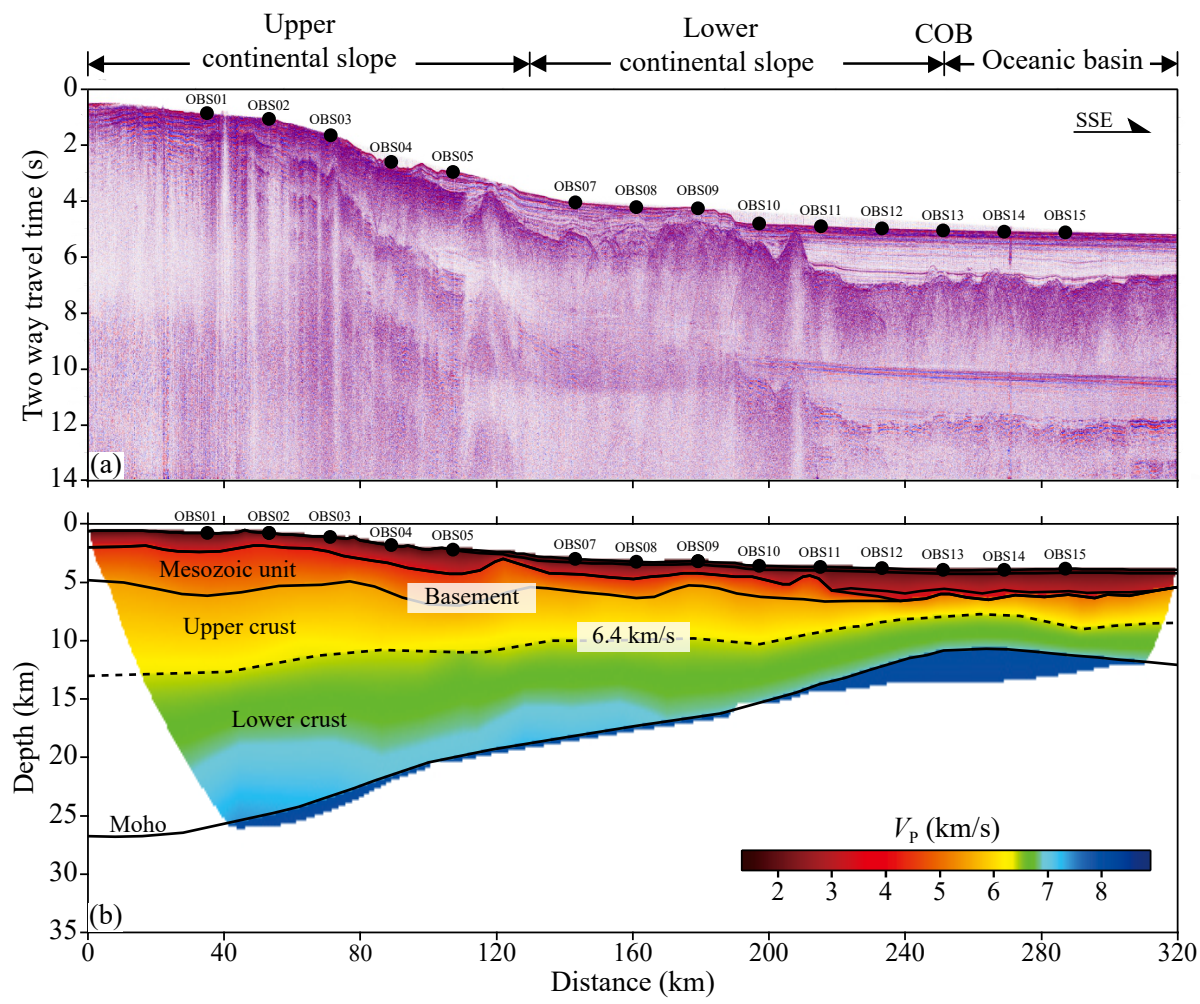

Figure 2. (a) Four-channel seismic reflection image of the OBS2016-2 profile. OBS positions are shown by black circles. (b) The P-wave velocity model derived from forward modeling of P-wave phases along the profile (Wan XL, 2018).

OBS12. Two isolated high-velocity zones (with $V_{\mathrm{P}}$ of $7.0-7.5 \mathrm{~km} / \mathrm{s}$ and $7.0-7.3 \mathrm{~km} / \mathrm{s}$, respectively) are found in the lower crust under the continental slope. This $V_{\mathrm{p}}$ model is used as the starting model for $V_{\mathrm{S}}$ modeling.

\subsection{S-Wave Velocity Model}

The S-wave modeling is based on the initial $V_{P}$ model geometry (Figure $2 \mathrm{~b}$ ). The $V_{S}$ model can be produced by fixing the depth nodes, but adjusting the Poisson's ratio for each layer and block of 
the $V_{P}$ model, and determining the location of P-S conversion for each arrival. During this stage, the interface depths and $V_{P}$ were kept fixed, and only the Poisson's ratio in each block was changed to improve the agreement between calculated and observed travel times. The $V_{\mathrm{P}} / V_{\mathrm{S}}$ ratio model can then be obtained by dividing $V_{\mathrm{P}}$ by $V_{\mathrm{S}}$.

Two types of S-wave arrivals, PPS and PSS, can be identified in the radial components. The PPS wave travels initially as a P-wave and is converted into S-wave at an interface on the way up, whereas the PSS wave is converted into S-wave on the way down, often at the seafloor or a sediment-crust interface (Au and Clowes, 1984; Tan PC et al., 2016). The PSS phases are the main S-wave phases that give direct estimates of $V_{S}$ in the crust.

A reduction velocity of $6 \mathrm{~km} / \mathrm{s}$ was applied to identify PPS and PSS phases. Figure 3 compares the vertical and radial components of OBS13. Identification of S-waves was based on their kinematic and dynamic features such as travel time (Figure $3 a-b$ ), apparent velocity, and particle motion (Figure $3 \mathrm{e}-\mathrm{f}$ ). The $\mathrm{S}$-wave in the radial component is slower than the P-wave in the vertical component. Three-dimensional particle motion sections show that the motion of a $\mathrm{P}$ arrival is predominantly vertical whereas the motion of an $\mathrm{S}$ arrival is mainly horizontal (Figure $3 e-f$ ).

To confirm the conversion mode, we calculated the apparent velocities of several converted phases in OBS09 (Table 1). Usually, the S-wave phases of the PPS mode have the same or smaller apparent velocities as the corresponding $\mathrm{P}$-wave phases, while the
S-wave phases of the PSS mode have much smaller apparent velocities. The apparent velocity of PPSs4 phases is $5.17 \mathrm{~km} / \mathrm{s}$, close to the apparent velocity of $\mathrm{Pg}$ phases, but for the PSSucs4 phases, the apparent velocity is $2.88 \mathrm{~km} / \mathrm{s}$, much smaller than $\mathrm{Pg}$ phase velocity of $5.64 \mathrm{~km} / \mathrm{s}$ (Table 1). If we further compare vertical with radial components (Figure 9), we can see that the PPSs4 phases have the same offset with Pg phases, but shorter travel times, while the PSSucs4 phases have smaller offsets and longer travel times. After confirming the conversion mode, the modeling exercise was then performed from sediment to mantle at each station by repeatedly changing the Poisson's ratio and converting interfaces until all the calculated arrivals fit well with picked phases. Then, all of the S-wave phases are assigned to the suitable interfaces.

Examples of PPS and PSS arrival picks and their modeled fits show that most of the P-S conversions occurred at top Mesozoic sediment, sedimentary basement, and the Moho, where exist large velocity or impedance contrasts (Figures 4-6). The model is primarily constrained by $\mathrm{S}$ waves in the upper (PSSuc phase) and lower (PSSlc phase) crust. Table 2 summarizes numbers of picks, picking error, root-mean-square (RMS) misfit, $\chi^{2}$ values (normalized misfit between calculated and observed travel time), and conversion interfaces.

The uncertainty in the S-wave modeling largely depends on the uncertainty in the P-wave model (Digranes et al., 1998). High-quality and numerous $\mathrm{P}$-wave arrivals provide good structural controls on our S-wave model. The uncertainties of interpreted travel-
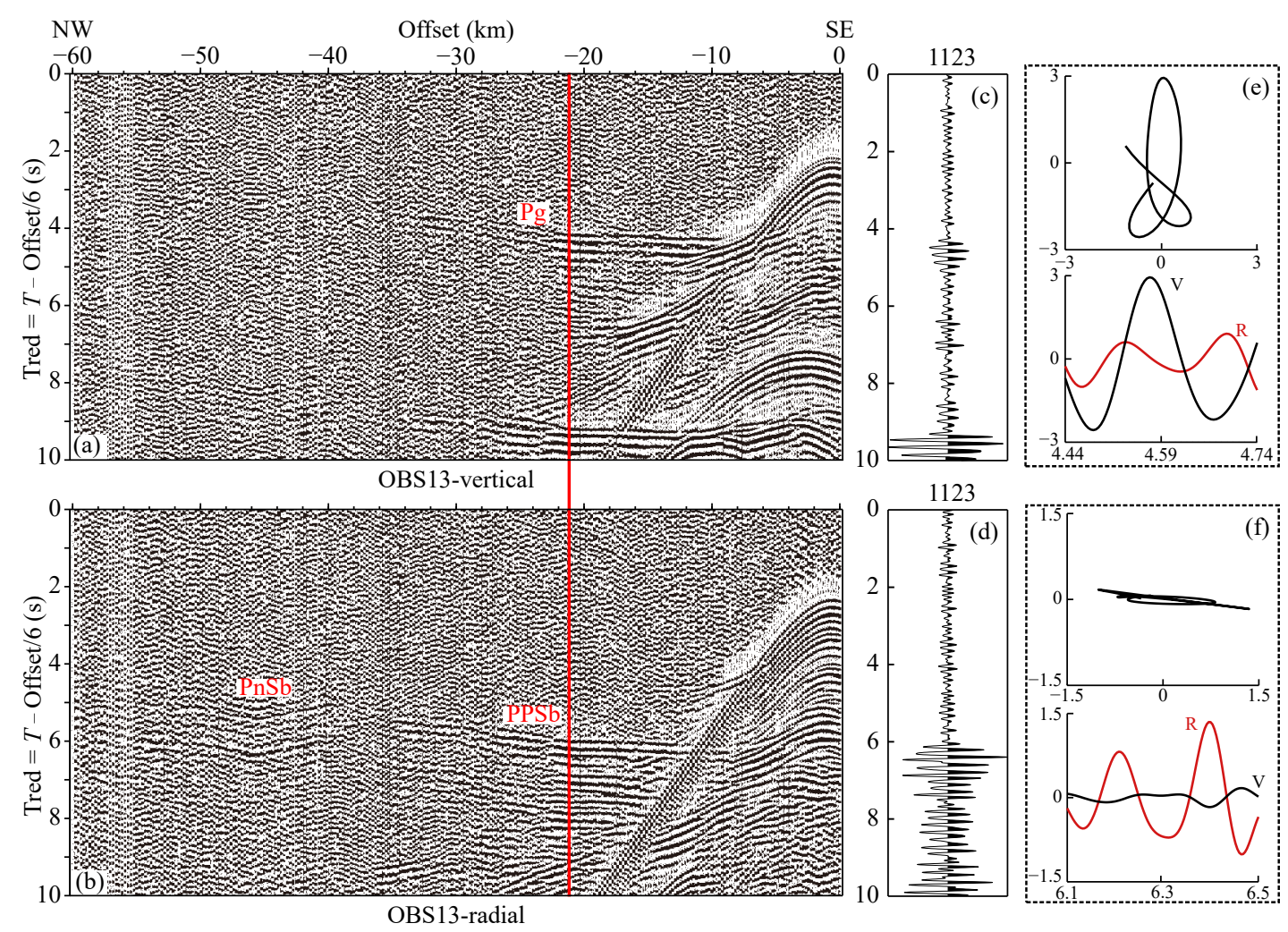

Figure 3. Vertical (a) and radial (b) components of OBS13 reduced by $6 \mathrm{~km} / \mathrm{s}$ (after 3-10 Hz band-pass filtering). (c) and (d) show the single-trace waveform of Trace 1123 in the vertical and radial component, respectively. (e) and (f) show the particle displacements of Trace 1123 in the vertical (4.44-4.74 s) and the radial (6.10-6.50 s) component sections, respectively. 
Table 1. Apparent velocities and phases in the record of OBS09

\begin{tabular}{|c|c|c|c|c|c|c|}
\hline \multirow{2}{*}{ Offset $(\mathrm{km})$} & \multicolumn{3}{|c|}{ Vertical component } & \multicolumn{3}{|c|}{ Radial component } \\
\hline & Reduced time (s) & Apparent velocity $(\mathrm{km} / \mathrm{s})$ & Phases & Reduced time (s) & Apparent velocity $(\mathrm{km} / \mathrm{s})$ & Phases \\
\hline \multirow[t]{2}{*}{-62 to -8} & $2.6-3.5$ & 5.64 & $\mathrm{Pg}$ & $4-5$ & 5.17 & PPSs4 \\
\hline & & & & $6.7-9.6$ & 2.88 & PSSucs4 \\
\hline \multirow[t]{2}{*}{$11-56$} & $3.6-4.1$ & 5.11 & $\mathrm{Pg}$ & $4.8-5.3$ & 4.67 & PPSs4 \\
\hline & & & & $8.7-10.2$ & 2.58 & PSSucs4 \\
\hline
\end{tabular}

time curves are generally within $50-160 \mathrm{~ms}$. During the simulation, we control the limit range of the Poisson's ratios ( \pm $0.01-0.04$ ) by keeping the mismatch between calculated and observed travel time within the picking uncertainty. With fixed $V_{\mathrm{P}}$ variations of $\pm 0.01-0.04$ in the Poisson's ratio lead to uncertainties of $\pm 0.01-0.2 \mathrm{~km} / \mathrm{s}$ and $\pm 0.03-0.16$ in calculated $V_{\mathrm{S}}$ and $V_{\mathrm{P}} / V_{\mathrm{S}}$ ratios, respectively.

A statistical measure of fit in chi-squared $\left(\chi^{2}\right)$ close to one is used to evaluate the mismatch between observed and calculated travel times (Zelt and Smith, 1992). After the S-wave modeling, the fitting RMS errors are less than $200 \mathrm{~ms}$ and $\chi^{2}$ are less than 2 for most of the S-wave phases (Table 2). The ray coverage map (Figure 7c) of all observed arrival locations further shows that the crust and most interfaces are well covered by 10-40 times, indicating high reliability and resolution of our S-wave model.

\section{S-Wave Velocity Structure and Implications on}

\section{Lithology}

In this section, we infer crustal lithology from P- and S- wave velocities and the $V_{\mathrm{P}} / V_{\mathrm{S}}$ ratio model (Figure $7 \mathrm{~b}$ ).


Figure 4. Seismic records, interpretation, and ray tracing of OBS09. (a) Comparison of interpreted (colored) PPS and PSS modes and calculated (solid) travel time curves for OBS09. (b) Ray-paths through the model for the calculated PPS arrivals. (c) Same as (b) for PSS arrivals. Solid lines denote rays of $\mathrm{P}$-waves and dotted lines denote rays of $\mathrm{S}$-waves. 

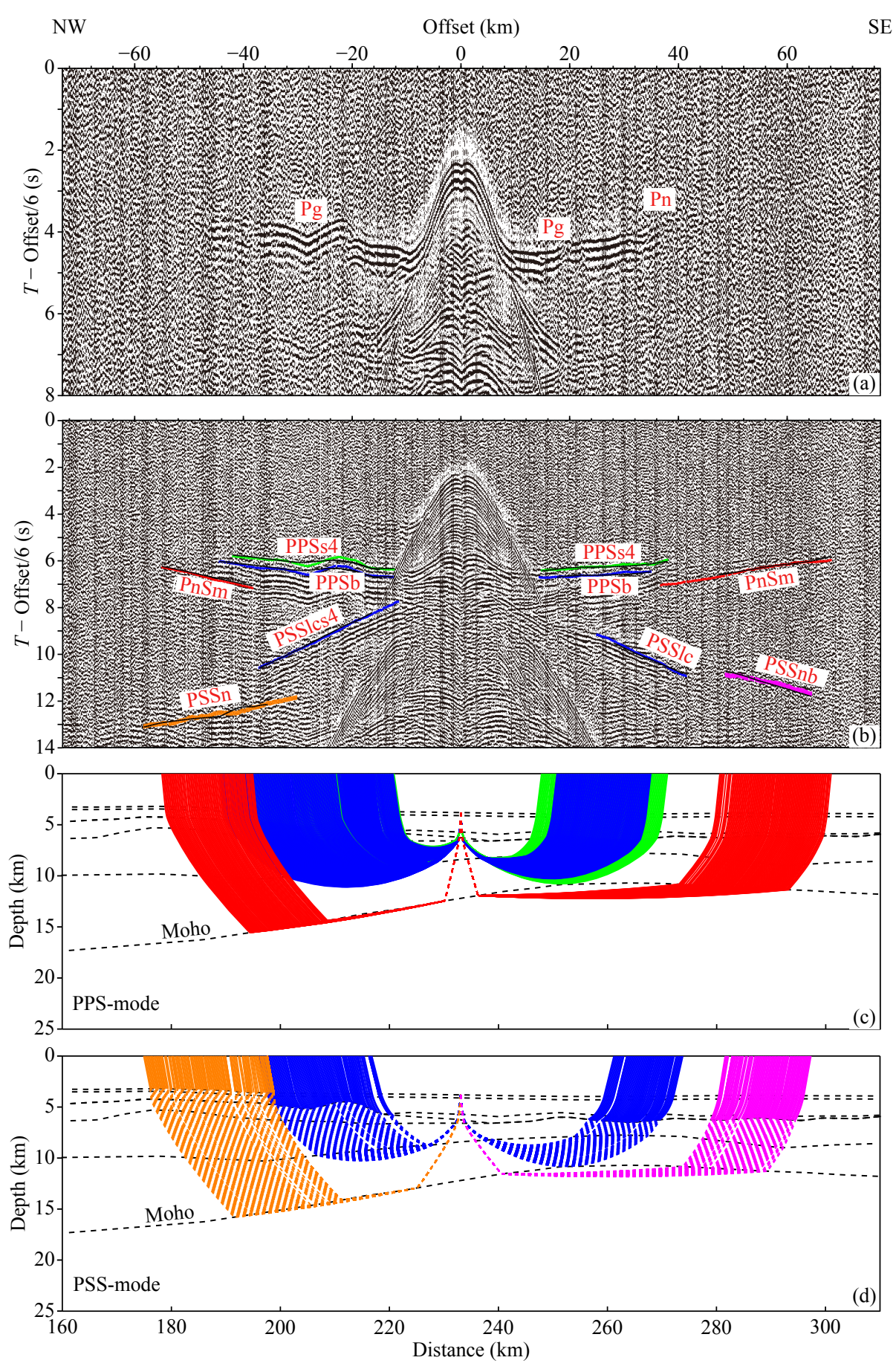

Figure 5. Seismic records, interpretation, and ray tracing of OBS12. (a) Vertical component of OBS12. (b) Radial component of OBS12 and interpreted (colored) PPS and PSS modes and calculated (solid) travel time curves are shown. (c) Ray-paths through the model for the calculated PPS arrivals. (d) Same as (c) for PSS arrivals.

\subsection{Sedimentary Layers}

Our models show that the $V_{\mathrm{S}}$ increases while the $V_{\mathrm{P}} / V_{\mathrm{S}}$ ratio decreases with depth through the sedimentary layers (Figure 7a-b). There are three Cenozoic sedimentary layers. The uppermost layer is characterized by very high $V_{\mathrm{P}} / V_{S}(4.2-6.6)$ and low $V_{S}$ $(0.3-0.45 \mathrm{~km} / \mathrm{s})$, particularly in the lower slope and oceanic basin. The other two Cenozoic sedimentary layers have $V_{S}$ of $0.6-1.5$ $\mathrm{km} / \mathrm{s}$ and $V_{\mathrm{P}} / V_{\mathrm{S}}$ ratios of 2.0-3.2. The increased confining pressure with depth reduces porosity and closes cracks, thereby decreas- ing $V_{\mathrm{P}} / V_{\mathrm{S}}$ ratios (Christensen and Mooney, 1995; Sato and Ito, 2001). We thus attribute the observed vertical decrease in $V_{P} / V_{S}$ ratio to increased compaction and consolidation of the sedimentary rocks.

The Mesozoic sedimentary layer at the Chaoshan Depression along our profile has a maximum thickness of $5 \mathrm{~km}, V_{\mathrm{S}}$ of 2.4-3.1 $\mathrm{km} / \mathrm{s}$, and $V_{\mathrm{P}} / V_{\mathrm{S}}$ ratios of 1.74-1.78; the layer pinches out southwards to the COB. These results of the Mesozoic sedimentary lay- 

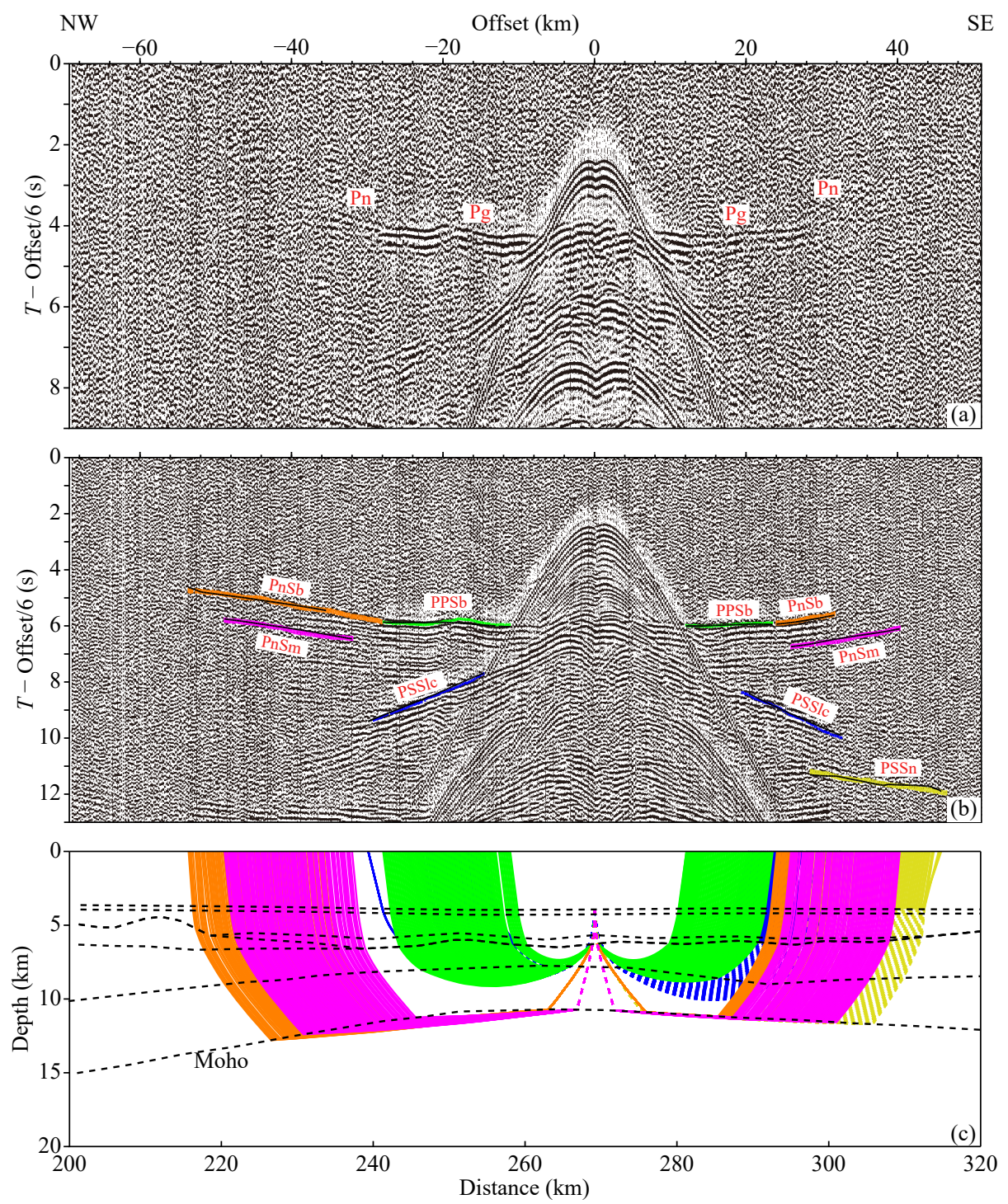

Figure 6. Seismic records, interpretation, and ray tracing of OBS14. (a) Vertical component of OBS14. (b) Radial component of OBS14 and interpreted (colored) PPS and PSS modes and calculated (solid) travel time curves are shown. (c) Ray-paths through the model for the calculated PPS and PSS arrivals.

Table 2. Numbers of picks, picking errors, RMS misfits, $\chi^{2}$ values, conversion mode and conversion interface (P-S interface) for phases identified along profile OBS2016-2 in the S-wave modeling

\begin{tabular}{|c|c|c|c|c|c|c|c|}
\hline OBS & Mode & Phase & No. of rays & Uncertainty & RMS & $x^{2}$ & P-S interface \\
\hline \multirow{6}{*}{1} & \multirow{4}{*}{ PPS } & PPSs4s4 & 141 & 0.05 & 0.048 & 0.915 & Upper Mesozoic \\
\hline & & PPSs4 & 337 & 0.08 & 0.049 & 0.974 & Upper Mesozoic \\
\hline & & PPSb & 292 & 0.07 & 0.059 & 1.394 & Basement \\
\hline & & PmSm & 153 & 0.09 & 0.064 & 0.504 & Moho \\
\hline & \multirow{2}{*}{ PSS } & PSSuc & 181 & 0.16 & 0.078 & 2.421 & Seafloor \\
\hline & & PSSIC & 157 & 0.12 & 0.056 & 1.269 & Upper Mesozoic \\
\hline \multirow{5}{*}{2} & \multirow{4}{*}{ PPS } & PPSs4s4 & 181 & 0.05 & 0.064 & 1.632 & Upper Mesozoic \\
\hline & & PPSucs4 & 273 & 0.05 & 0.053 & 1.126 & Upper Mesozoic \\
\hline & & PPSb & 364 & 0.07 & 0.056 & 1.262 & Basement \\
\hline & & PmSm & 107 & 0.12 & 0.092 & 1.049 & Moho \\
\hline & PSS & PSSuc & 315 & 0.15 & 0.065 & 1.695 & Seafloor \\
\hline
\end{tabular}


Continued from Table 2

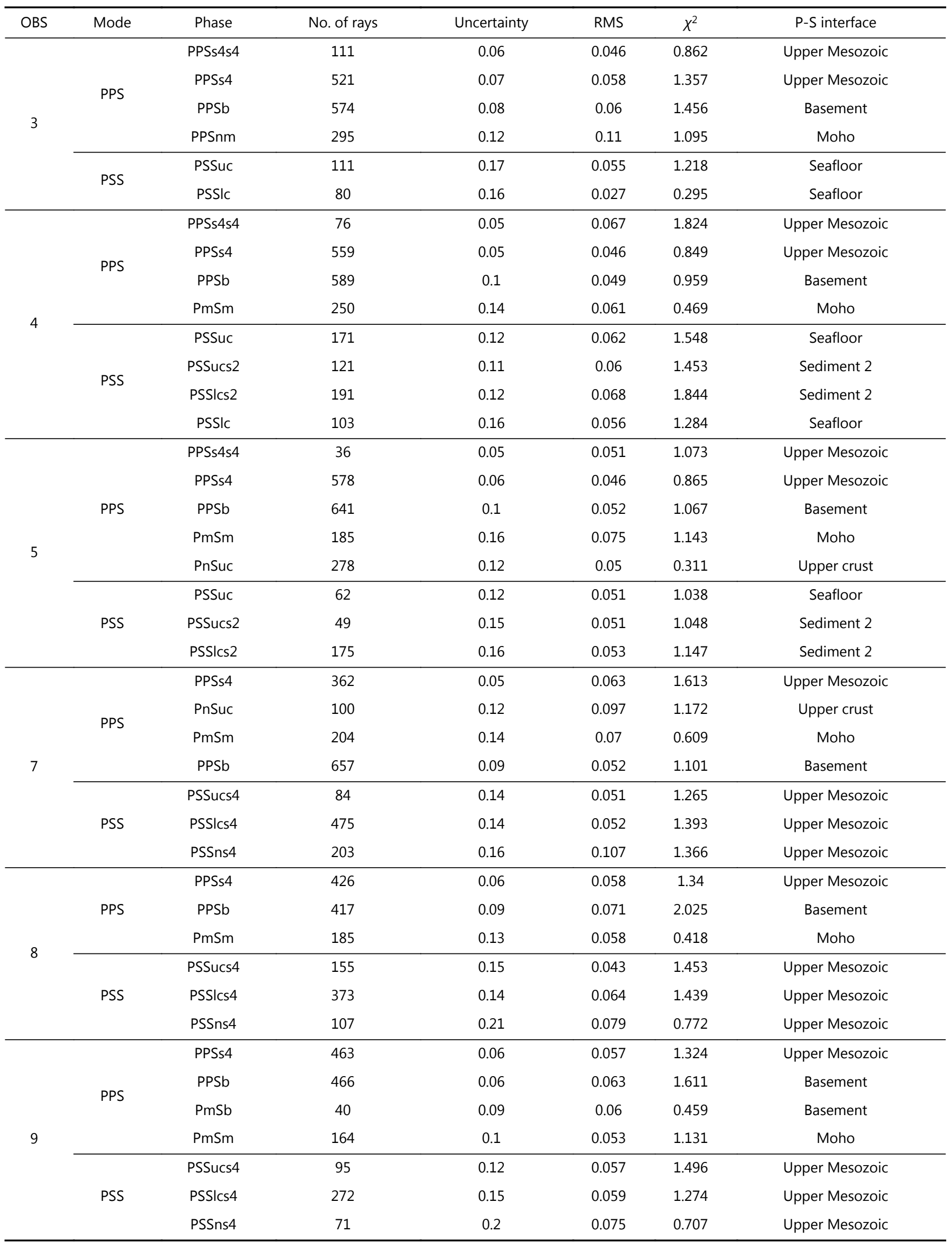


Continued from Table 2

\begin{tabular}{|c|c|c|c|c|c|c|c|}
\hline OBS & Mode & Phase & No. of rays & Uncertainty & RMS & $\chi^{2}$ & P-S interface \\
\hline \multirow{8}{*}{10} & \multirow{5}{*}{ PPS } & PPSs4 & 303 & 0.05 & 0.06 & 1.422 & Upper Mesozoic \\
\hline & & PnSs4 & 47 & 0.05 & 0.059 & 0.439 & Upper Mesozoic \\
\hline & & PPSb & 418 & 0.08 & 0.062 & 1.545 & Basement \\
\hline & & $\mathrm{PnSb}$ & 75 & 0.09 & 0.062 & 0.482 & Basement \\
\hline & & $\mathrm{PmSm}$ & 169 & 0.1 & 0.041 & 0.68 & Moho \\
\hline & \multirow{3}{*}{ PSS } & PSSucs4 & 88 & 0.1 & 0.053 & 1.141 & Upper Mesozoic \\
\hline & & PSSIcs4 & 142 & 0.14 & 0.053 & 1.148 & Upper Mesozoic \\
\hline & & PSSIcb & 37 & 0.15 & 0.05 & 1.017 & Basement \\
\hline \multirow{6}{*}{11} & \multirow{3}{*}{ PPS } & PPSs4 & 244 & 0.05 & 0.039 & 0.626 & Upper Mesozoic \\
\hline & & PPSb & 283 & 0.07 & 0.038 & 0.582 & Basement \\
\hline & & PmSm & 115 & 0.09 & 0.054 & 1.17 & Moho \\
\hline & \multirow{3}{*}{ PSS } & PSSucs4 & 60 & 0.1 & 0.058 & 1.347 & Upper Mesozoic \\
\hline & & PSSIcs4 & 178 & 0.1 & 0.046 & 0.858 & Upper Mesozoic \\
\hline & & PSSIcb & 70 & 0.15 & 0.042 & 0.731 & Basement \\
\hline \multirow{7}{*}{12} & \multirow{3}{*}{ PPS } & PPSs4 & 251 & 0.05 & 0.062 & 1.529 & Upper Mesozoic \\
\hline & & PPSb & 248 & 0.07 & 0.065 & 1.713 & Basement \\
\hline & & $\mathrm{PnSm}$ & 179 & 0.09 & 0.058 & 1.354 & Moho \\
\hline & \multirow{4}{*}{ PSS } & PSSIcs4 & 98 & 0.1 & 0.04 & 0.653 & Upper Mesozoic \\
\hline & & PSSn & 104 & 0.15 & 0.081 & 0.815 & Seafloor \\
\hline & & PSSIcb & 76 & 0.1 & 0.05 & 0.94 & Basement \\
\hline & & PSSnb & 80 & 0.1 & 0.094 & 1.094 & Basement \\
\hline \multirow{6}{*}{13} & \multirow{3}{*}{ PPS } & PPSb & 127 & 0.05 & 0.057 & 1.322 & Basement \\
\hline & & $\mathrm{PnSb}$ & 123 & 0.09 & 0.064 & 0.507 & Basement \\
\hline & & $\mathrm{PnSm}$ & 90 & 0.12 & 0.087 & 0.944 & Moho \\
\hline & \multirow{3}{*}{ PSS } & PSSIcs4 & 137 & 0.11 & 0.06 & 1.452 & Upper Mesozoic \\
\hline & & PSSn & 55 & 0.15 & 0.048 & 0.291 & Seafloor \\
\hline & & PSSIcb & 82 & 0.15 & 0.066 & 1.748 & Basement \\
\hline \multirow{5}{*}{14} & \multirow{3}{*}{ PPS } & PPSb & 141 & 0.05 & 0.06 & 1.47 & Basement \\
\hline & & $\mathrm{PnSb}$ & 131 & 0.09 & 0.04 & 0.197 & Basement \\
\hline & & $\mathrm{PnSm}$ & 154 & 0.12 & 0.046 & 0.265 & Moho \\
\hline & \multirow{2}{*}{ PSS } & PSSIcb & 135 & 0.1 & 0.063 & 1.633 & Basement \\
\hline & & PSSn & 84 & 0.15 & 0.111 & 1.531 & Seafloor \\
\hline \multirow{4}{*}{15} & \multirow{2}{*}{ PPS } & PPSb & 170 & 0.05 & 0.037 & 0.559 & Basement \\
\hline & & $\mathrm{PnSm}$ & 125 & 0.1 & 0.062 & 0.481 & Moho \\
\hline & \multirow{2}{*}{ PSS } & PSSb & 98 & 0.15 & 0.068 & 1.883 & Basement \\
\hline & & PSSnb & 59 & 0.15 & 0.064 & 1.121 & Basement \\
\hline
\end{tabular}

er are similar to those along the OBS2006-3 profile (Wei XD et al., 2011), which reported a maximum thickness of $8 \mathrm{~km}, V_{S}$ of 2.6-3.0 $\mathrm{km} / \mathrm{s}$ and $V_{\mathrm{P}} / V_{\mathrm{S}}$ ratios of $1.74-1.80$. The good consolidation of Mesozoic sediments is revealed by the relatively low $V_{\mathrm{P}} / V_{\mathrm{S}}$ ratio and high $V_{S}$, which also contribute to the P-S conversions.

\subsection{Upper Continental Slope (Model Distance of 0-130 km)}

The $V_{S}$ in the upper crust of the upper slope is $3.1-3.6 \mathrm{~km} / \mathrm{s}$, and the estimated $V_{\mathrm{P}} / V_{\mathrm{S}}$ ratio is $1.75-1.77$, characterizing a felsic granite composition typical of continental crust, in good agreement 

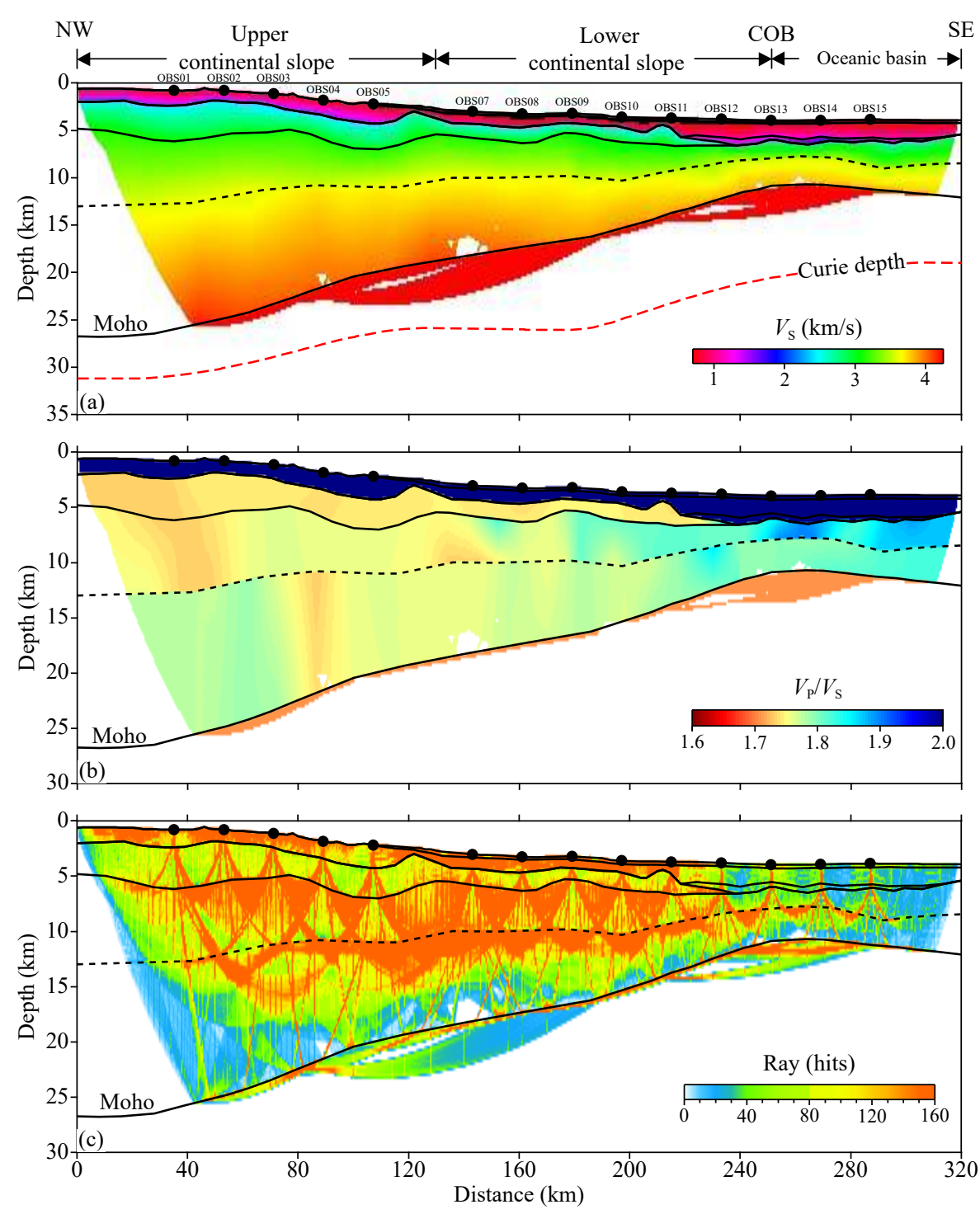

Figure 7. (a) S-wave velocity model of OBS2016-2 profile. (b) Calculated $V_{\mathrm{P}} / V_{\mathrm{S}}$ ratios based on $V_{\mathrm{P}}$ and $V_{\mathrm{S}}$ velocity modeling. (c) Ray coverage of the tomographic inversion (in 0.5 by $0.25 \mathrm{~km}$ distance-depth grid).

with the average $V_{\mathrm{P}} / V_{\mathrm{S}}$ ratio of 1.768 obtained by Christensen and Mooney (1995). The $V_{S}$ in the lower crust is $3.6-4.2 \mathrm{~km} / \mathrm{s}$ and $V_{\mathrm{P}} / V_{\mathrm{S}}$ ratios are of 1.73-1.78, suggesting a wide spectrum of rock composition from felsic to mafic, based on the results summarized in Figure 8.

\subsection{Lower Continental Slope (Model Distance of 130-233 km)}

This section includes the continent-ocean transition zone, which is highly extended during rifting (Song TR, 2016). The upper crustal $V_{S}$ is $3.0-3.6 \mathrm{~km} / \mathrm{s}$ and $V_{\mathrm{P}} / V_{\mathrm{S}}$ ratios are $1.74-1.76$, indicating a thinned crust and felsic composition similar to the results of Zhao $\mathrm{MH}$ et al. (2010). $V_{\mathrm{S}}$ is $3.6-4.1 \mathrm{~km} / \mathrm{s}$ and $V_{\mathrm{P}} / V_{\mathrm{S}}$ ratios are $1.75-1.81$ in the lower crust, also suggesting a rock composition from felsic to mafic (Figure 8).

\subsection{Oceanic Basin (Model Distance of 233-320 km)}

The Moho depth near the COB varies from $\sim 11$ to $\sim 13 \mathrm{~km}$ below sea level, somewhat shallower than in the surrounding areas, probably due to the mantle upwelling confirmed by previous re- flection seismic interpretations (Song TR, 2016). The $V_{S}$ of oceanic crust is $2.7-3.8 \mathrm{~km} / \mathrm{s}$, and $V_{\mathrm{P}} / V_{\mathrm{S}}$ ratios are $1.80-1.89$. These high $V_{\mathrm{P}} / V_{\mathrm{S}}$ ratios indicate a basic-ultrabasic composition (Wei XD et al., 2011).

\section{Discussion}

\subsection{The Nature of High Velocity Zones}

Our S-wave velocity model with quantifiable uncertainty allows the interpretable spatial variations of the $V_{\mathrm{P}} / V_{S}$ ratio to be determined. Plots of the $V_{\mathrm{P}} / V_{\mathrm{S}}$ ratio versus $V_{\mathrm{P}}$ give good geological discrimination (Eccles et al., 2009). Figure 8 shows such a plot for the average HVZ properties (defined by $V_{P}>6.9 \mathrm{~km} / \mathrm{s}$ and $V_{S}>$ $3.9 \mathrm{~km} / \mathrm{s}$ ) at $10 \mathrm{~km}$ intervals in the continent slope. The average lower crustal temperature and pressure are estimated at each position. Curie-point depths derived from magnetic anomalies (Li CF and Wang J, 2016) are used to calculate crustal temperature assuming a geothermal gradient of $25^{\circ} \mathrm{C} / \mathrm{km}$ (Stein and Stein, 1992). Densities $\rho$ (Table 3 ) of sedimentary layers, upper and lower crust, 


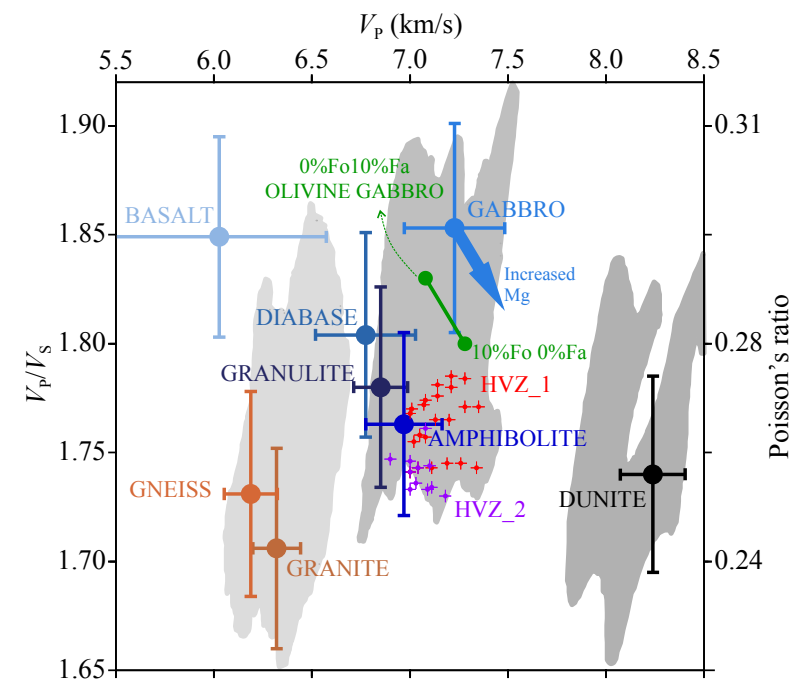

Figure 8. $V_{\mathrm{P}}$ versus $V_{\mathrm{P}} / V_{\mathrm{S}}$ plot of the high velocity zones under continental lower crust corrected to a pressure of $535 \mathrm{MPa}$ and a temperature of $380^{\circ} \mathrm{C}$. The properties of gabbro, diabase, amphibolite, gneiss, basalt, and granite (Christensen, 1996) have been corrected to $535 \mathrm{MPa}$ pressure. The properties of dunite and mafic granulite are calculated using the approach of Hacker and Abers (2004). The properties of an Oman olivine gabbro with $10 \%$ olivine (Browning, 1984) shown in pale green have been calculated (at 535 $\mathrm{MPa}$ and $380^{\circ} \mathrm{C}$ ) for systematic iron-magnesium substitution of fayalite ( $\mathrm{Fa}$ ) and forsterite (Fo) to show the $V_{\mathrm{P}}$ and $V_{\mathrm{P}} / V_{\mathrm{S}}$ trend of increasing magnesium content. The shadow parts are felsic, mafic, and ultramafic rocks, modified from Rudnick and Fountain (1995). The first lower crustal HVZ (HVZ_1) samplings at $10 \mathrm{~km}$ intervals from 40 to $100 \mathrm{~km}$ in horizontal distance are shown by red stars, while the second HVZ (HVZ_2) samplings from 120 to $170 \mathrm{~km}$ are shown by purple stars.

calculated using the relationship of $V_{\mathrm{P}}$ and $\rho$ (Christensen and Mooney, 1995; Gardner et al., 1974) are used to obtain crustal pressure. The properties of rocks have been corrected to a constant pressure and temperature of $535 \mathrm{MPa}$ and $380^{\circ} \mathrm{C}$, respectively, by estimating the rock type and calculating pressure and temperature gradients using the approach of Hacker and Abers (2004). These measurements strongly suggest that high velocities observed in the lower crust of the continental slope are from a mafic igneous composition. Zhao $\mathrm{MH}$ et al. (2010) revealed that the $V_{S}$ and $V_{\mathrm{P}} / V_{\mathrm{S}}$ ratios of a high-velocity layer from the nearby profile OBS2001 are 4.0-4.2 km/s and 1.76-1.94, respectively. Similarly, Wei XD et al. (2011) showed that the $V_{\mathrm{S}}$ and $V_{\mathrm{P}} / V_{\mathrm{S}}$ ratios of a high-velocity layer from profile OBS2006-3 are $4.0-4.2 \mathrm{~km} / \mathrm{s}$ and
$1.73-1.78$, respectively. These previous studies also suggest a mafic composition. However, our result shows that lower crust high velocities are not in a single layer, but in several high-velocity zones (HVZ). They are more likely to be amphibolite in composition rather than gabbro or mafic gneisses, because most of our data points with relatively low $V_{\mathrm{P}} / V_{\mathrm{S}}$ ratios fall close to the amphibolite facies but far away from the gabbro zone (Figure 8).

The magmatic activities were not strong before and during the SCS rifting and seafloor spreading and no high-velocity anomaly was found onland South China (Yin ZX et al., 1999). Post-spreading magmatic activities became more active, and more seamounts developed parallel to the faults in this stage ( $\mathrm{Ru} \mathrm{K}$ and Pigott, 1986; Song XX et al., 2017). Therefore, we infer that the high-velocity anomalies may have been formed by magmatic underplating after the cessation of seafloor spreading.

The effect of magnesium on the $V_{\mathrm{p}} / V_{\mathrm{S}}$ ratios has been explored by calculating the trend of properties for an olivine gabbro from the Oman Ophiolite (Browning, 1984), with systematic substitution of magnesium for iron within the olivine (fayalite to forsterite) using the approach of Hacker and Abers (2004). This trend shows that, with increasing magnesium, the $V_{\mathrm{P}}$ increases but the $V_{\mathrm{P}} / V_{\mathrm{S}}$ ratio decreases, that is, the properties trend towards those of dunite (Figure 8). This indicates that the high velocity anomalies could also be caused by magnesium-rich gabbro produced from mantle melting at temperatures higher than normal. We further argue that the anomalies could be formed after the spreading stopped because significant episodic extensions ( 15.2 Ma and 5.2 Ma) may have thinned the lithosphere, leading to high heat flow (He LJ et al., 1998; Shi XB et al., 2003). Thermal contraction in the oceanic lithosphere may also trigger extension and decompressive melting along weak zones in the continental slope and the oceanic basin (Song XX et al., 2017). As a consequence, high- temperature melting would increase the $\mathrm{Mg}$ content at the expense of Fe (White et al., 1992) and reduced the $V_{\mathrm{P}} / V_{\mathrm{S}}$ ratio.

\subsection{Serpentinization in the Lower Crust and Upper Mantle} Serpentinization is formed by the hydration of olivine-rich ultramafic rocks at relatively low temperatures, which significantly lowers the compressional wave velocity of the primary peridotite (from 8 to $7.2-7.6 \mathrm{~km} / \mathrm{s}$ ), and increases magnetic susceptibility by nearly two orders of magnitude (Evans et al., 2013). Serpentinization can usually be found in magma-poor continental margins, where the continent-ocean transition zone is highly stretched and seawater can penetrate deep into mantle through cracks and fractures to form serpentinite. In the West Iberian margin, a lower crust layer under a thinned transition zone is found up to $4 \mathrm{~km}$

Table 3. Density calculation from seismic velocity for model layers

\begin{tabular}{|c|c|c|c|c|c|}
\hline \multirow{2}{*}{ Gardner's Rule (1974) } & \multirow{2}{*}{$\rho\left(\mathrm{g} / \mathrm{cm}^{3}\right)=1.74 \times V_{\mathrm{p}} 0.25$} & Sediment 1 & Sediment 2 & Sediment 3 & Sediment 4 \\
\hline & & 2.03 & 2.21 & 2.36 & 2.57 \\
\hline Christensen \& Mooney (1995)_10 km & $\rho=0.541+0.3601 \times V_{P}$ & \multicolumn{4}{|c|}{ Upper crust } \\
\hline \multirow{2}{*}{ Christensen \& Mooney (1995)_20 km } & \multirow{2}{*}{$\rho=0.444+0.3754 \times V_{P}$} & \multicolumn{4}{|c|}{ Lower crust } \\
\hline & & \multicolumn{4}{|c|}{3.05} \\
\hline
\end{tabular}


thick with $V_{P}$ of 7.3-7.9 km/s (Chian et al., 1999; Dean et al., 2000), which represents mantle peridotite with mean bulk serpentinization of $<25 \%$ from the seawater influx during rifting along large numbers of faults (Dean et al., 2000).

In our previous $V_{\mathrm{P}}$ inversion model (Wan $\mathrm{XL}, 2018$ ), we also observed a high-velocity anomaly $\left(V_{P} 7.0-7.8 \mathrm{~km} / \mathrm{s}\right)$ with a maximum thickness of $4 \mathrm{~km}$ in the lower crust near the COB (from 210 to 280 $\mathrm{km}$ in offset) (Figure 9b). Analysis of 1-D velocity-depth profiles at this high-velocity zone indicated mantle/lower crust exhumation or serpentinization (Wan $\mathrm{XL}, 2018$ ). To further examine the nature of this high-velocity anomaly, we analyze the new $V_{\mathrm{P}} / V_{\mathrm{S}}$ ratios (Figure 9c) based on the $V_{\mathrm{P}}$ from tomographic inversion (Wan $\mathrm{XL}$, 2018) and our S-wave velocity.

The HVZ properties near the COB (from 210 to $280 \mathrm{~km}$ ) are plotted on a $V_{\mathrm{P}} / V_{\mathrm{S}}$ versus $V_{\mathrm{P}}$ diagram (Figure 10 ). The modelled properties are compared to laboratory results to test different hypotheses, e.g., whether the HVZ comprises gabbros, peridotites, or serpentinites. These measurements showed that the $V_{\mathrm{P}} / V_{\mathrm{S}}$ ratios of HVZ samples range from 1.85 to 1.96 , much higher than those of most mafic rocks. The plotted points distribute predominantly around serpentinized peridotites, but fewer around gabbro.

We then further draw a $V_{\mathrm{P}}$ versus $V_{\mathrm{P}} / V_{\mathrm{S}}$ plot of different degrees of serpentinization (Figure 11) to see how the HVZ relates to the ser- pentinization. Physical properties vary linearly with the degree of serpentinization, with $V_{P}$ decreasing from $8 \mathrm{~km} / \mathrm{s}$ in peridotite to $4.8 \mathrm{~km} / \mathrm{s}$ in serpentinite (Christensen, 1966). Our observed HVZ velocities $(7.0-7.8 \mathrm{~km} / \mathrm{s})$ and $V_{\mathrm{p}} / V_{\mathrm{S}}$ ratios $(1.85-1.96)$ fit well with the trend; most points are scattered around the partially serpentinized peridotite samples with $37-43 \%$ serpentinization. These data argue for serpentinization of uppermost mantle near the COB.

In general, marine free-air gravity anomalies vary with the bathymetry. However, we observe a high gravity anomaly (Figure 9a) near the flat $\mathrm{COB}$, correlating spatially to our identified zone with lower crust high velocity anomalies, mantle upwelling, and serpentinization near the COB. On the map view, this high gravity anomaly extends further east in a narrow zone parallel to the COB (Figure 12), indicating that this feature of mantle upwelling is widespread and is potentially more severe in the northeasternmost SCS than elsewhere. From reflection seismic interpretations, Song TR (2016) already identified this COB feature of mantle upwelling $\sim 200 \mathrm{~km}$ west to this line, but no appreciable high gravity anomalies were found there to be associated with this mantle upwelling (Figure 12). We suspect that mantle upwelling in other places was either too narrow or too premature to induce noticeable gravity anomalies.

Seismic data and geochemical studies reveal that the magmatic
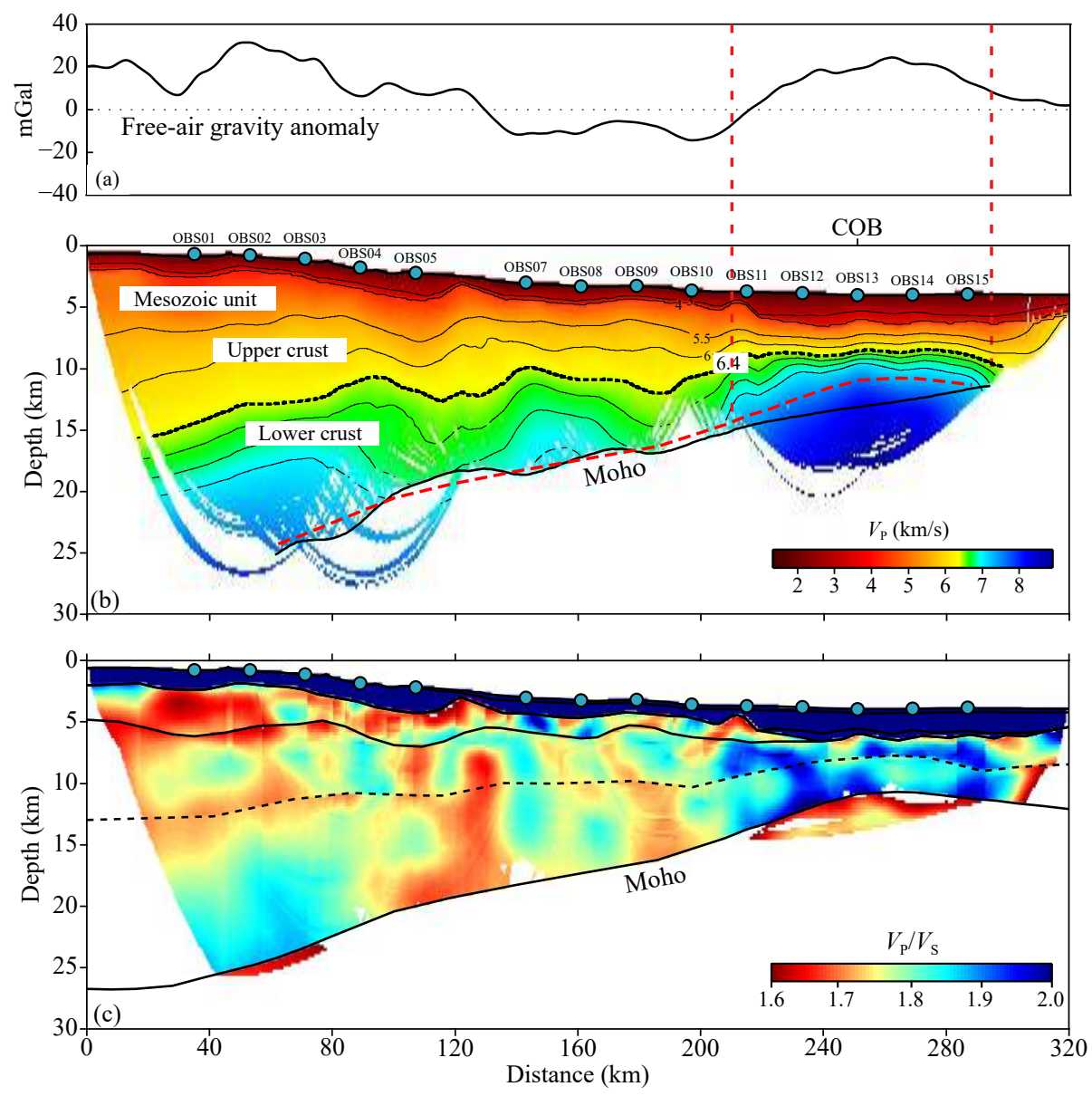

Figure 9. (a) Free-air gravity anomaly along OBS2016-2 profile. (b) The P-wave velocity model derived from tomographic inversion (Wan XL, 2018). The red line shows the Moho depth derived from forward modeling. (c) Calculated $V_{\mathrm{P}} / V_{\mathrm{S}}$ ratios. 


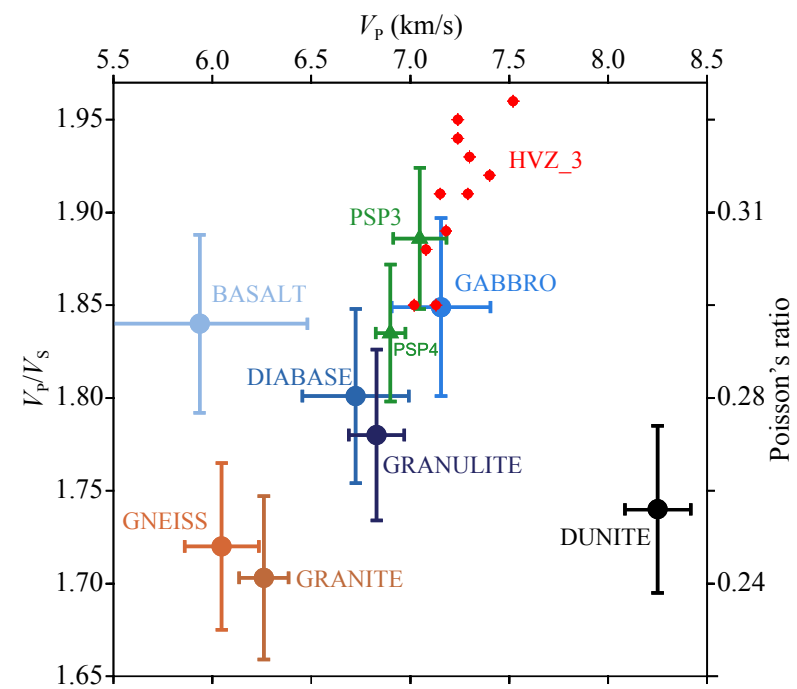

Figure 10. $V_{P}$ versus $V_{P} / V_{S}$ plot for the third high velocity anomaly (HVZ_3) at the COB corrected to a pressure of $255 \mathrm{MPa}$ and a temperature of $316^{\circ} \mathrm{C}$. Lower crust high velocity samplings at $10 \mathrm{~km}$ intervals from 210 to $280 \mathrm{~km}$ in the horizontal distance are shown by red circles. The properties of partially serpentinized peridotite (PSP) Samples 3 and 4 from Christensen (1966) have been corrected to the pressure of $255 \mathrm{MPa}$.

activities in the northeastern SCS continental margin were not strong during the incipient rifting and spreading (66-26 Ma) (e.g., Song XX et al., 2017; Fan CY et al., 2017; Xia SH et al., 2017). Based on magnetic data analysis, Li C-F et al. (2014) found that the full spreading rate of the East Subbasin was higher $(\sim 70 \mathrm{~km} /)$ at the beginning of seafloor spreading from $\sim 32$ to $\sim 29 \mathrm{Ma}$, and dropped to $\sim 25 \mathrm{~km} /$ on average from $\sim 29$ to $\sim 26 \mathrm{Ma}$. The slow spreading rates support a magma-starved northeastern SCS continental margin prone to serpentinization, since many titled faults

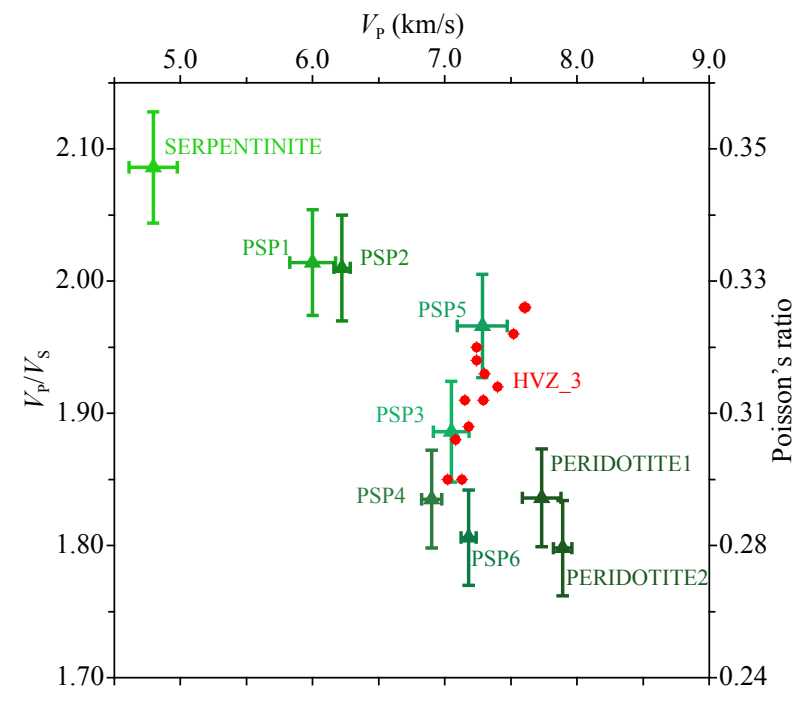

Figure 11. $V_{\mathrm{P}}$ versus $V_{\mathrm{P}} / V_{\mathrm{S}}$ plot for the third high velocity anomaly (HVZ_3) at the COB on the diagram for different grades of partially serpentinized peridotites (PSP) corrected to a pressure of $255 \mathrm{MPa}$ (Christensen, 1966).

have been revealed in the thinned continental-ocean transition zone and seawater can penetrate into the already upwelled mantle.

\section{Conclusion}

Converted S-wave arrival time has been inverted to produce crustal S-wave velocity model $\left(V_{S}\right)$ with good estimates of model uncertainty across the northeastern continental margin of the South China Sea (SCS). The velocities are constrained by highquality, densely-sampled seismic phases recorded by fourteen four-component ocean bottom seismometers (OBS). The crustal

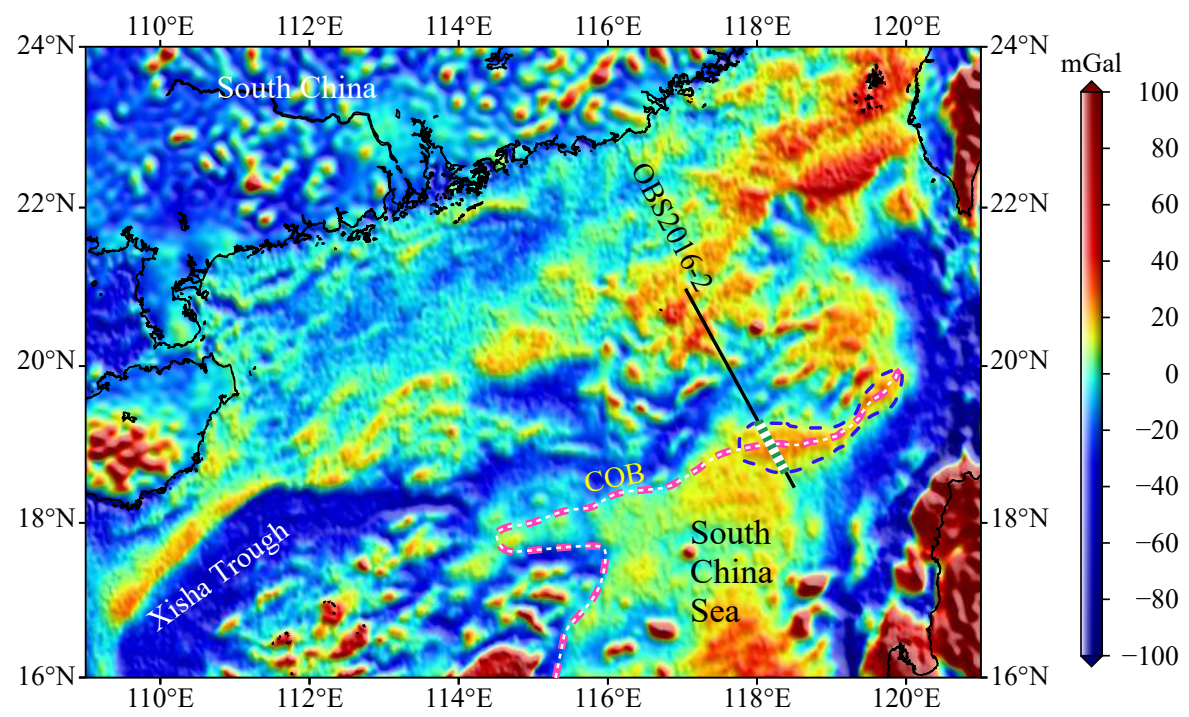

Figure 12. Free-air gravity anomaly (V21.1 from Sandwell and Smith, 2009; Sandwell et al., 2013) map of the Northern South China Sea. Black line shows the position of our seismic profile with interpreted zone of mantle upwelling/serpentinization in dashed green and white colors. The high gravity anomaly zone surrounded by the blue dashed line represents the interpreted areal distribution of the mantle upwelling/serpentinization subparallel to the COB of Li C-F and Song TR (2012) and Song TR (2016). 
scale $V_{\mathrm{S}}$ and $V_{\mathrm{P}} / V_{\mathrm{S}}$ ratios provide valuable information on mineralogy and lithology, particularly of lower crust high velocity anomalies.

In the continental slope, we find two isolated high-velocity zones in the lower crust. The $V_{\mathrm{P}} / V_{\mathrm{S}}$ versus $V_{\mathrm{P}}$ plot reveals a mafic composition, more likely to be of amphibolite rather than gabbro. Based on the effect of magnesium on the $V_{\mathrm{P}} / V_{\mathrm{S}}$ ratios, we further infer that the HVZs could be caused by magnesium-rich gabbro from post-spreading mantle melting at temperatures higher than normal.

The third high-velocity zone of $\sim 70 \mathrm{~km}$ wide located between thinned continental crust and oceanic crust is identified with Pwave velocities of $7.0-7.8 \mathrm{~km} / \mathrm{s}$ and $V_{\mathrm{P}} / V_{\mathrm{S}}$ ratios of $1.85-1.96$. These observed velocities and $V_{\mathrm{P}} / V_{\mathrm{S}}$ values suggest serpentinization to an extent of $37-43 \%$ in a layer up to $4 \mathrm{~km}$ thick beneath the top oceanic crust. High free-air gravity anomalies over a relatively flat $C O B$ further support the imaged high lower crustal velocity anomalies, mantle upwelling, and serpentinization, which appear to be most evident in the northeasternmost SCS. Seawater can penetrate down into the uppermost mantle through fractures in the thinned oceanic crust in the COB of the SCS.

\section{Acknowledgments}

We thank South China Sea Institute of Oceanology (SCSIO) for providing R/V Shiyan-2 to carry out this experiment, sponsored by Oceanographic Research Vessel Sharing Plan (NORC2016-08) of National Natural Science Foundation of China. We thank all researchers and sailors on Shiyan-2 for collecting the OBS and MCS data. We also thank chief scientist Hongbo Zheng, and team leader Enyuan He for their important contributions to this voyage. Comments from two anonymous reviewers helped improved this paper. This research is also funded by National Natural Science Foundation of China (Grant Nos. 41776057, 41761134051, 91858213,41730532 and 91428039). Data processing and mapping is supported by GMT (Wessel and Smith, 1998), Raylnvr (Zelt and Smith, 1992), and Tomo2D (Korenaga et al., 2000).

\section{References}

Au, D., and Clowes, R. M. (1984). Shear-wave velocity structure of the oceanic lithosphere from ocean bottom seismometer studies. Geophys. J. R. astr. Soc., 77(1), 105-123. https://doi.org/10.1111/j.1365-246x.1984.tb01927.x

Bautista, B. C., Bautista, M. L. P., Oike, K., Wu, F. T., and Punongbayan, R. S. (2001). A new insight on the geometry of subducting slabs in northern Luzon, Philippines. Tectonophysics, 339(3-4), 279-310.

https://doi.org/10.1016/S0040-1951(01)00120-2

Briais, A., Patriat, P., and Tapponnier, P. (1993). Updated interpretation of magnetic anomalies and seafloor spreading stages in the South China Sea: implications for the tertiary tectonics of Southeast Asia. J. Geophys. Res. Solid Earth, 98(B4), 6299-6382. https://doi.org/10.1029/92JB02280

Browning, P. (1984). Cryptic variation within the cumulate sequence of the Oman ophiolite: magma chamber depth and petrological implications. Geol. Soc. Spec. Publ., 13(1), 71-82. https://doi.org/10.1144/GSL.SP.1984.013.01.07

Castagna, J. P., Batzle M. L., and Eastwood R. L. E. (1985). Relationships between compressional-wave and shear-wave velocities in clastic silicate rocks. Geophysics, 50(4), 571-581. https://doi.org/10.1190/1.1441933

Chian, D., Louden K. E., Minshull, T. A., and Whitmarsh, R. B. (1999). Deep structure of the ocean-continent transition in the Southern Iberia abyssal plain from seismic refraction profiles: Ocean Drilling Program (Legs 149 and 173) transect. J. Geophys. Res. Solid Earth, 104(B4), 7443-7462. https://doi.org/10.1029/1999JB900004

Christensen, N. I. (1966). Elasticity of ultrabasic rocks. J. Geophys. Res., 71(24), 5921-5931. https://doi.org/10.1029/JZ071i024p05921

Christensen, N. I., and Mooney, W. D. (1995). Seismic velocity structure and composition of the continental crust: a global view. J. Geophys. Res. Solid Earth, 100(B6), 9761-9788. https://doi.org/10.1029/95JB00259

Christensen, N. I. (1996). Poisson's ratio and crustal seismology. J. Geophys. Res. Solid Earth, 101(B2), 3139-3156. https://doi.org/10.1029/95JB03446

Dean, S. M., Minshull, T. A., Whitmarsh, R. B., and Louden, K. E. (2000). Deep structure of the ocean-continent transition in the Southern Iberia Abyssal Plain from seismic refraction profiles: the IAM-9 transect at $40^{\circ} 20^{\prime} \mathrm{N}$. J. Geophys. Res. Solid Earth, 105(B3), 5859-5885. https://doi.org/10.1029/1999JB900301

Digranes, P., Mjelde, P., Kodaira, S., Shimamura, H., Kanazawa, T., Shiobara, H., and Berg, E. W. (1998). A regional shear-wave velocity model in the central Vøring basin, N. Norway, using three-component ocean bottom seismographs. Tectonophysics, 293(3-4), 157-174. https://doi.org/10.1016/S0040-1951(98)00093-6

Ding, W. W., Li, J. B., Clift, P. D., and IODP Expedition 349 Scientists. (2016). Spreading dynamics and sedimentary process of the Southwest Sub-basin, South China Sea: constraints from multi-channel seismic data and IODP Expedition 349. J. Asian Earth Sci., 115, 97-113. https://doi.org/10.1016/j.jseaes.2015.09.013

Eccles, J. D., White, R. S., and Christie, P. A. F. (2009). Identification and inversion of converted shear waves: case studies from the European North Atlantic continental margins. Geophys. J. Int., 179(1), 381-400. https://doi.org/10.1111/j.1365-246X.2009.04290.x

Evans, B. W., Hattori, K., and Baronnet, A. (2013). Serpentinite: what, why, where?. Elements, 9(2), 99-106. https://doi.org/10.2113/gselements.9.2.99

Fan, C. Y., Xia, S. H., Zhao, F., Sun, J. L., Cao, J. H., Xu, H. L., and Wan, K. Y. (2017). New insights into the magmatism in the northern margin of the South China Sea: spatial features and volume of intraplate seamounts. Geochem. Geophys. Geosyst., 18(6), 2216-2239. https://doi.org/10.1002/2016GC006792

Gao, J. W., Wu, S. G., McIntosh, K., Mi, L. J., Yao, B. C., Chen, Z. M., and Jia, L. K. (2015). The continent-ocean transition at the mid-northern margin of the South China Sea. Tectonophysics, 654, 1-19. https://doi.org/10.1016/j.tecto.2015.03.003

Gardner, G. H. F., Gardner, L. W., and Gregory, A. R. (1974). Formation velocity and density-the diagnostic basics for stratigraphic traps. Geophysics, 39(6), 770-780. https://doi.org/10.1190/1.1440465

Hacker, B. R., and Abers, G. A. (2004). Subduction factory 3: An excel worksheet and macro for calculating the densities, seismic wave speeds, and $\mathrm{H}_{2} \mathrm{O}$ contents of minerals and rocks at pressure and temperature. Geochem. Geophys. Geosyst., 5(1), Q01005. https://doi.org/10.1029/2003GC000614

Hall, R., and Spakman, W. (2002). Subducted slabs beneath the eastern Indonesia -Tonga region: insights from tomography. Earth Planet. Sci. Lett., 201(2), 321-336. https://doi.org/10.1016/s0012-821x(02)00705-7

He, L. J., Xiong, L. P., and Wang, J. Y. (1998). The geothermal characteristics in South China Sea. China Offshore Oil and Gas, 12(2), 87-90.

Holbrook, W. S., Mooney, W. D., and Christensen, N. I. (1992). The seismic velocity structure of the deep continental crust. In D. M. Fountion, et al. (Eds.), Continental Lower Crust (pp. 1-43). Amsterdam: Elsevier.

Hu, D. K., Zhou, D., Wu, X. J., and He, M. (2008). Origin of high magnetic anomaly belt in northeastern South China Sea as indicated by geophysical inversion. J. Trop. Oceanograph. (in Chinese), 27(1), 32-37. https://doi.org/10.3969/j.issn.1009-5470.2008.01.007

Korenaga, J., Holbrook, W. S., Kent, G. M., Kelemen, P. B., Detrick, R. S., Larsen, H. C., Hopper, J. R., and Dahl-Jensen, T. (2000). Crustal structure of the southeast Greenland margin from joint refraction and reflection seismic tomography. J. Geophys. Res. Solid Earth, 105(B9), 21591-21614. https://doi.org/10.1029/2000JB900188

Leloup, P. H., Lacassin, R., Tapponnier, P., Schárer, U., Zhong, D. L., Liu, X. H., 
Zhang, L. S., Ji, S. C., and Trinh, P. T. (1995). The Ailao Shan-Red river shear zone (Yunnan, China), tertiary transform boundary of Indochina. Tectonophysics, 251(1-4), 3-84. https://doi.org/10.1016/00401951(95)00070-4

Li, C.-F., Zhou, Z. Y., Hao, H. J., Chen, H. J., Wang, J. L., Chen, B., and Wu, J. S. (2008). Late Mesozoic tectonic structure and evolution along the presentday northeastern South China Sea continental margin. J. Asian Earth Sci., 31(4-6), 546-561. https://doi.org/10.1016/j.jseaes.2007.09.004

Li, C.-F., Shi, X. B., Zhou, Z. Y., Li, J. B., Geng, J. H., and Chen, B. (2010). Depths to the magnetic layer bottom in the South China Sea area and their tectonic implications. Geophys. J. Int., 182(3), 1229-1247. https://doi.org/10.1111/j.1365-246X.2010.04702.x

Li, C.-F., and Song, T. R. (2012). Magnetic recording of the Cenozoic oceanic crustal accretion and evolution of the South China Sea basin. Chin. Sci. Bull., 57(24), 3165-3181. https://doi.org/10.1007/s11434-012-5063-9

Li, C.-F., Xu, X., Lin, J., Sun, Z., Zhu, J., Yao, Y. J., Zhao, X. X., Liu, Q. S., Kulhanek, D. K., ... Zhang, G. L. (2014). Ages and magnetic structures of the South China Sea constrained by deep tow magnetic surveys and IODP Expedition 349. Geochem. Geophys. Geosyst., 15(2), 4958-4983. https://doi.org/10.1002/2014GC005567

Li, C.-F., and Wang, J. (2016). Variations in Moho and Curie depths and heat flow in eastern and southeastern Asia. Mar. Geophys. Res., 37(1), 1-20. https://doi.org/10.1007/s11001-016-9265-4

Li, Y. Q., Yan, P., Wang, Y. L., and Zhong, G. J. (2017). Deep crustal structure revealed by ocean bottom seismic profile OBS2015-1 in southwestern Dongsha waters. J. Trop. Oceanogr. (in Chinese), 36(5), 83-92. https://doi.org/10.11978/2016122

Mjelde, R., Raum, T., Digranes, P., Shimamura, H., Shiobara, H., and Kodaira, S. (2003). Vp/Vs ratio along the Vøring margin, NE Atlantic, derived from OBS Data: implications on lithology and stress field. Tectonophysics, 369(3-4), 175-197. https://doi.org/10.1016/S0040-1951(03)00198-7

Neidell, N. S. (1985). Land applications of shear waves. Leading Edge, 4(11), 32-44. https://doi.org/10.1190/1.1439115

Nissen, S. S., Hayes, D. E., Buhl, P., Diebold, J., Yao, B. C., Zeng, W. J., and Chen, Y. Q. (1995). Deep penetration seismic soundings across the northern margin of the South China Sea. J. Geophys. Res. Solid Earth, 100(B11), 22407-22433. https://doi.org/10.1029/95JB01866

Pubellier, M., Monnier, C., Maury, R., and Tamayo, R. (2004). Plate kinematics, origin and tectonic emplacement of supra-subduction ophiolites in SE Asia. Tectonophysics, 392(1-4), 9-36. https://doi.org/10.1016/j.tecto.2004.04.028

Ru, K., and Pigott, J. D. (1986). Episodic rifting and subsidence in the South China Sea. AAPG Bull., 70(9), 1136-1155. https://doi.org/10.1029/JB091iB10p10513

Rudnick, R. L., and Fountain, D. M. (1995). Nature and composition of the continental crust: a lower crustal perspective. Rev. Geophys., 33(3), 267-309. https://doi.org/10.1029/95RG01302

Sandwell, D. T., and Smith, W. H. F. (2009). Global marine gravity from retracked Geosat and ERS-1 altimetry: ridge segmentation versus spreading rate. J. Geophys. Res. Solid Earth, 114(B1), B01411. https://doi.org/10.1029/2008JB006008

Sandwell, D. T., Garcia, E., Soofi, K., Wessel, P., Chandler, M., and Smith, W. H. F. (2013). Toward 1-mGal accuracy in global marine gravity from CryoSat-2, Envisat, and Jason-1. Lead Edge, 32(8), 892-899. https://doi.org/10.1190/tle32080892.1

Sato, $\mathrm{H}_{\text {, }}$ and Ito, K. (2001). $\mathrm{H}_{2} \mathrm{O}$ fluid distribution in mantle rock at $1 \mathrm{GPa}$ ?: constraints from Vs-Vp/Vs diagram. Bull. Earthq. Res. Inst. Univ., Tokyo, 76(3), 305-310.

Savva, D., Pubellier, M., Franke, D., Chamot-Rooke, N., Meresse, F., Steuer, S., and Auxietre, J. L. (2014). Different expressions of rifting on the South China Sea margins. Mar. Pet. Geol., 58, 579-598.

https://doi.org/10.1016/j.marpetgeo.2014.05.023

Shi, H. S., and Li, C. F. (2012). Mesozoic and early Cenozoic tectonic convergence-to-rifting transition prior to opening of the South China Sea. Int. Geol. Rev., 54(15), 1801-1828.

https://doi.org/10.1080/00206814.2012.677136
Shi, X. B., Qiu, X. L., Xia, K. Y., and Zhou, D. (2003). Heat flow characteristics and its tectonic significance of South China Sea. J. Trop. Oceanogr. (in Chinese), 22(2), 63-73. https://doi.org/10.3969/j.issn.1009-5470.2003.02.007

Song, T. R. (2016). The crustal structure and lithosphere rupture mechanism of the continental-ocean transition zone of the South China Sea [Ph. D. thesis]. Shanghai: Tongji Unversity.

Song, X. X., Li, C. F., Yao, Y. J., and Shi, H. S. (2017). Magmatism in the evolution of the South China Sea: geophysical characterization. Mar. Geol., 394, 4-15. https://doi.org/10.1016/j.margeo.2017.07.021

Stein, C. A., and Stein, S. (1992). A model for the global variation in oceanic depth and heat flow with lithospheric age. Nature, 359(6391), 123-129. https://doi.org/10.1038/359123a0

Sun, Z., Sun, L. T., Zhou, D., Cai, D. S., Li, X. S., Zhong, Z. H., Jiang, J. Q., and Fan, H. (2009). Discussion on the South China Sea evolution and lithospheric breakup through 3d analogue modeling. Earth Sci--J. China Univ. Geosci. (in Chinese), 34(3), 435-447. https://doi.org/10.3321/j.issn:10002383.2009.03.008

Tan, P. C., Breivik, A. J., Trønnes, R. G., Mjelde, R., Azuma, R., and Eide, S. (2016). Crustal structure and origin of the Eggvin Bank west of Jan Mayen, NE Atlantic. J. Geophys. Res. Solid Earth, 122(1), 43-62. https://doi.org/10.1002/2016JB013495

Tapponnier, P., Peltzer, G., Le Dain, A. Y., Armijo, R., and Cobbold, P. (1982). Propagating extrusion tectonics in Asia: new insights from simple experiments with plasticine. Geology, 10(2), 611-616. https://doi.org/10.1130/0091-7613(1982)10<611:petian>2.0.co;2

Taylor, B., and Hayes, D. E. (1980). The tectonic evolution of the South China Basin. In D. E. Hayes (Ed.), The Tectonic and Geologic Gvolution of Southeast Asian Seas and Islands (pp. 89-104). Washington: AGU. https://doi.org/10.1029/GM023p0089

Taylor, B., and Hayes, D. E. (1983). Origin and history of the South China Sea basin. In D. E. Hayes (Ed.), The Tectonic and Geologic Evolution of Southeast Asian Seas and Islands (pp. 23-56). Washington: AGU. https://doi.org/10.1029/GM027p0023

Wan, K. Y., Xia, S. H., Cao, J. H., Sun, J. L., and Xu, H. L. (2017). Deep seismic structure of the northeastern South China Sea: origin of a high-velocity layer in the lower crust. J. Geophys. Res. Solid Earth, 122(4), 2831-2858. https://doi.org/10.1002/2016jb013481

Wan, X. L. (2018). Seismic velocity structures of the transitional crust across the northeastern margin of the South China Sea [Master's thesis]. Shanghai: Tongji University.

Wang, T. K., Chen, M. K., Lee, C. S., and Xia, K. Y. (2006). Seismic imaging of the transitional crust across the northeastern margin of the South China Sea. Tectonophysics, 412(3-4), 237-254. https://doi.org/10.1016/j.tecto.2005.10.039

Wei, X. D., Zhao, M. H., Ruan, A. G., Qiu, X. L., Hao, T. Y., Wu, Z. L., Ao, W., and Xiong, H. (2011). Crustal structure of shear waves and its tectonic significance in the mid-northern continental margin of the South China Sea. Chinese J. Geophys. (in Chinese), 54(12), 3150-3160. https://doi.org/10.3969/j.issn.0001-5733.2011.12.015

Wessel, P., and Smith, W. H. F. (1998). New, improved version of generic mapping tools released. Eos., 79(47), 579. https://doi.org/10.1029/98EO00426

White, R. S., McKenzie, D., and O'Nions, R. K. (1992). Oceanic crustal thickness from seismic measurements and rare earth element inversions. J. Geophys. Res. Solid Earth, 97(B13), 19683-19715. https://doi.org/10.1029/92JB01749

Xia, S. H., Fan, C. Y., Sun, J. L., Cao, J. H., Zhao, F., and Wan, K. Y. (2017). Characteristics of late Cenozoic magmatic activities on the northern margin of South China Sea and their tectonic implications. Mar. Geol. Quat. Geol. (in Chinese), 37(6), 25-33. https://doi.org/10.16562/j.cnki.02561492.2017.06.003

Yan, P., Zhou, D., and Liu, Z. S. (2001). A crustal structure profile across the northern continental margin of the South China Sea. Tectonophysics, 338(1), 1-21. https://doi.org/10.1016/S0040-1951(01)00062-2

Yan, P., Deng, H., Liu, H. L., Zhang, Z. R., and Jiang, Y. K. (2006). The temporal and spatial distribution of volcanism in the South China Sea region. J. Asian 
Earth Sci., 27(5), 647-659. https://doi.org/10.1016/j.jseaes.2005.06.005

Yin, Z. X., Lai, M. H., Xiong, S. B., Liu, H. B., Teng, J. W., and Kong, X. R. (1999). Crustal structure and velocity distribution from deep seismic sounding along the profile of Lianxian-Boluo-Gangkou in South China. Chinese J. Geophys. (in Chinese), 42(3), 383-392. https://doi.org/10.3321/j.issn:00015733.1999.03.011

Zelt, C. A., and Smith, R. B. (1992). Seismic traveltime inversion for 2-D crustal velocity structure. Geophys. J. Int., 108(1), 16-34. https://doi.org/10.1111/j.1365-246X.1992.tb00836.x

Zhang, L., Zhao, M. H., Qiu, X. L., and Wang, Q. (2016). Recent progress of converted shear-wave phase identification in Nansha Block using ocean bottom seismometers data. J. Trop. Oceanogr. (in Chinese), 35(1), 61-71. https://doi.org/10.11978/2015025

Zhao, M. H., Qiu, X. L., Xia, S. H., Xu, H. L., Wang, P., Wang, T. K., Lee, C. S., and Xia, K. Y. (2010). Seismic structure in the northeastern South China Sea: S-wave velocity and $\mathrm{Vp} / \mathrm{Vs}$ ratios derived from three-component OBS data. Tectonophysics, 480(1-4), 183-197. https://doi.org/10.1016/j.tecto.2009.10.004

Zhou, D., Wang, W. Y., Wang, J. L., Pang, X., Cai, D. S., and Sun, Z. (2006). Mesozoic subduction-accretion zone in northeastern South China Sea inferred from geophysical interpretations. Sci. China Ser. D., 49(5), 471-482. https://doi.org/10.1007/s11430-006-0471-9 